\title{
Huaier extract enhances the treatment efficacy of paclitaxel in breast cancer cells via the $\mathrm{NF}-\kappa \mathrm{B} / \mathrm{I} \kappa \mathrm{B} \alpha$ pathway
}

\author{
LIU YANG, ZHENCHUAN SONG, XINLE WANG, WEI YANG, MEIQI WANG and HUAN LIU \\ Breast Center, Fourth Hospital of Hebei Medical University, Shijiazhuang, Hebei 050035, P.R. China
}

Received April 6, 2017; Accepted September 21, 2017

DOI: $10.3892 /$ or.2017.6024

\begin{abstract}
Breast cancer is considered as the most common malignant disease in women. Huaier extract, a type of traditional Chinese medicine, has been found to have antitumor activity. In the present study, we aimed to investigate whether the combined treatments of paclitaxel and Huaier extract may improve treatment efficacy in breast cancer cells. Human breast cancer cell lines MCF-7 and MDA-MB-231 were used to evaluate the antitumor efficacy of Huaier extract and paclitaxel both in vitro and in vivo. Using proliferation assays and flow cytometry, we found that both Huaier extract and paclitaxel decreased cell viability and induced cell apoptosis in a time- and dose-dependent manner. The combined treatments were more effective than monotherapy. Huaier extract induced cycle arrest in the G0/G1 phase, and paclitaxel arrested the cell cycle in the G2/M phase. Furthermore, the results of real-time PCR and western blotting revealed that Huaier extract decreased p65 and c-Met expression and increased $\mathrm{I} \kappa \mathrm{B} \alpha$ expression, while paclitaxel increased p65 expression and reduced $\mathrm{I} \kappa \mathrm{B} \alpha$ and $\mathrm{c}-\mathrm{Met}$ expression. Consistent with the in vitro results, both Huaier extract and paclitaxel exerted a significant inhibitory effect on xenografted tumor growth, and the combined therapies revealed the most marked inhibitory effect. Collectively, our results indicated that Huaier extract increased the antitumor effect of paclitaxel therapy in breast cancer cells. The molecular mechanisms may be involved in the inhibition of the $\mathrm{NF}-\kappa \mathrm{B}$ pathway and c-Met expression.
\end{abstract}

\section{Introduction}

Breast cancer is the most frequently diagnosed cancer in women. Globally, 1.3 million new cases are diagnosed annually (1). China accounted for $12.2 \%$ of all newly diagnosed global cases and $9.6 \%$ of all breast cancer-related deaths worlwide in

Correspondence to: Professor Zhenchuan Song, Breast Center, Fourth Hospital of Hebei Medical University, 169 Tianshan Street, Shijiazhuang, Hebei 050035, P.R. China

E-mail: songzhch@hotmail.com

Key words: breast cancer, paclitaxel, huaier extract, combined therapies, $\mathrm{NF}-\kappa \mathrm{B} / \mathrm{I} \kappa \mathrm{B} \alpha$ pathway
2008 (2), and since 1990s the incidence in China has increased more than twice as fast as that of global rates, particularly in urban areas (3). Although treatments of breast cancer have significantly been improved in surgery, radiotherapy and molecular targeted therapy, chemotherapy is still the major method. Chemotherapy reduced the risk of disease recurrence and metastasis (4). However, the chemotherapy resistance is still a major limitation in clinical treatment. Hence, new drugs or new therapeutic combinations are required to enhance chemosensitization and therapeutic efficacy (5).

Paclitaxel, one of the most important anticancer drugs, has been widely used for chemotherapy in ovarian, non-small cell lung cancer, and head and neck cancer, for almost 40 years, and it is also the first-line chemotherapy drug used in breast cancer $(6,7)$. Paclitaxel prompts tubulin polymerization by binding $\beta$-tubulin. By stabilizing the microtubule polymer and preventing microtubules from disassembly, paclitaxel arrests the cell cycle in the G2/M phases and induces cell death (8-10). However, chemotherapy resistance limits the effect of paclitaxel and influences the prognosis of patients. Thus, it is particularly important to enhance the sensitivity of cancer cells to paclitaxel.

Trametes robiniophila Murr. (Huaier), a type of traditional Chinese medicine, has been widely used in China for $\sim 1,600$ years (11). Huaier extract is the fungus extracted twice with hot water and the effective ingredient is proteoglycan, containing $41.53 \%$ polysaccharides, $12.93 \%$ amino acids and $8.72 \%$ water (12-14). However, the anticancer effect of proteoglycan is less effective than that of the Huaier extract (15). It has been demonstrated that the main anticancer mechanisms of Huaier are achieved by inhibiting the growth and proliferation of cancer cells, inducing apoptosis, decreasing drug resistance in cancer cells, and improving immunity as well $(16,17)$. In vitro experiments revealed that Huaier extract inhibited the growth of hepatocarcinoma and human lung adenocarcinoma cells $(18,19)$. Huaier extract could inhibit the growth of ER $\alpha$-positive breast cancer cells through the $\mathrm{ER} \alpha / \mathrm{NF}-\kappa \mathrm{B}$ pathway (20). A recent study reported that Huaier extract synergized with tamoxifen to increase autophagy and cell apoptosis in MCF-7 breast cancer cells, which was more effective than monotherapy (21).

In 1986, NF- $\kappa \mathrm{B}$ was discovered as a nuclear factor that binds to the enhancer element of the immunoglobulin $\kappa$ lightchain of activated B cells (22). Aberrant activation of NF- $\kappa$ B is frequently found in various solid tumors and hematological 
malignancies. NF- $\mathrm{NB}$ family members and their regulated genes are associated with tumor development, tumor cell proliferation, survival, angiogenesis, invasion, metastasis and drug resistance (23). I $\kappa \mathrm{B}$ is the specific intracellular inhibitor of NF- $\kappa$ B. In most cell types, NF- $\kappa \mathrm{B}$ is present in an inactive form, where it is complexed with I $\mathrm{B}$ in the cytoplasm (24). A previous study observed persistent activation of $N F-\kappa B$ in hepatocellular carcinoma cell lines, and suggested that inhibition of NF- $\mathrm{B}$ signaling markedly sensitized HCC cells to doxorubicin-induced apoptosis (25). In the chemotherapy, drug resistance is an important problem, as well as the expression levels of multidrug resistant (MDR) proteins, apoptosis and anti-apoptosis genes are the main factors of tumor chemosensitivity (26). Moreover, $\mathrm{NF}-\kappa \mathrm{B}$ is closely associated with apoptosis and mediates cell proliferation and survival. $\mathrm{NF}-\kappa \mathrm{B}$ can activate a variety of anti-apoptosis genes, such as $\mathrm{Bcl}-\mathrm{xL}, \mathrm{Bfl} / \mathrm{A} 1$ and Bcl-2. Furthermore, the downregulation of $\mathrm{NF}-\kappa \mathrm{B}$ and different Bcl-2 family members leads to enhanced chemosensitization or radio-sensitization of multiple human cancers (27).

In the present study, we demonstrated for the first time that Huaier extract combined with paclitaxel induced cell apoptosis and enhanced paclitaxel drug sensitivity in breast cancer cells via the $\mathrm{NF}-\kappa \mathrm{B}$ pathway.

\section{Materials and methods}

Cell lines and reagents. ER-positive breast cancer cell line MCF-7 and triple-negative breast cancer cell line MDA-MB-231 were obtained from The Cell Bank of the Chinese Academy Sciences (Shanghai, China). Huaier extract was kindly provided by Gaitianli Medicine Co. Ltd. (Jiangsu, Chain). One gram Huaier extract was dissolved in $10 \mathrm{ml}$ of complete RPMI-1640 medium and sterilized with a $0.22-\mu \mathrm{m}$ filter to obtain $100 \mathrm{mg} / \mathrm{ml}$ stock solution at $4^{\circ} \mathrm{C}$. Paclitaxel was purchased from Yangzijiang Medicine Co. Ltd. (Jiangsu, China). p65, IкB $\alpha$ and c-Met monoclonal antibodies were purchased from Abcam (Cambridge, UK). Rabbit anti-human polyclonal $\beta$-actin antibody was purchased from Bioworld Technology Inc. (St. Louis, MO, USA). The secondary antirabbit antibody was purchased from Qiaoyi Biotechnics Co. Lit (Shanghai, China).

Cell culture. Both MCF-7 and MDA-MB-231 cells were cultured in RPMI-1640 medium (Gibco-BRL, Thermo Fisher Scientific, Waltham, MA, USA) with $10 \%$ fetal bovine serum (FBS; Biological Industries Israel Beit-Haemek Ltd., Kibbutz Beit-Haemek, Israel), $100 \mathrm{U} / \mathrm{ml}$ penicillin and $100 \mu \mathrm{g} / \mathrm{ml}$ streptomycin. MCF-7 and MDA-MB-231 cells were routinely cultured at $37^{\circ} \mathrm{C}$ with $5 \% \mathrm{CO}_{2}$ in a humidified incubator.

Cell viability assay (CCK-8 assay). Cell viability was determined by Cell Counting Kit-8 (CCK-8) assay. Both MCF-7 and MDA-MB-231 cells were seeded into 96-well plates at a density of $5 \times 10^{4}$ cells/well in $100 \mu \mathrm{l}$ RPMI-1640 medium. After being cultured in $5 \% \mathrm{CO}_{2}$, in a $37^{\circ} \mathrm{C}$ incubator overnight, the RPMI-1640 medium in each well was treated with different concentrations of solutions $(0,2,4,8,10$ and $16 \mathrm{mg} / \mathrm{ml}$ of Huaier extract; 0, 0.001, 0.01, 0.1, 1 and $10 \mu \mathrm{g} / \mathrm{ml}$ of paclitaxel, or combined therapies) and incubated for 0,24 or
$48 \mathrm{~h}$. Afterwards, $10 \mu \mathrm{l}$ of CCK-8 solution was added to each well for another $2 \mathrm{~h}$ at $37^{\circ} \mathrm{C}$. The absorbance at $450 \mathrm{~nm}$ was read using a microplate reader (BioTek, Winooski, VT, USA). The inhibitory rate of cell growth was calculated based on the following equation: Cell growth inhibition rate $=(1-$ experimental OD450/control OD450) x 100\%. Based on the statistical analysis of results, 4 and $8 \mathrm{mg} / \mathrm{ml}$ of Huaier extract and 0.01 and $0.1 \mu \mathrm{g} / \mathrm{ml}$ of paclitaxel were used to explore cell functional studies and mechanisms. For combined therapies in vitro, the cells were treated with $4 \mathrm{mg} / \mathrm{ml}$ Huaier extract $+0.01 \mu \mathrm{g} / \mathrm{ml}$ paclitaxel $(\mathrm{H} 4+\mathrm{P} 0.01)$ and $8 \mathrm{mg} / \mathrm{ml}$ Huaier extract $+0.1 \mu \mathrm{g} / \mathrm{ml}$ paclitaxel $(\mathrm{H} 8+\mathrm{P} 0.1)$ for $48 \mathrm{~h}$. Experiments were repeated three times, independently.

Flow cytometric analysis of the cell cycle and apoptosis. Cell apoptosis was performed using an FITC Annexin V apoptosis detection kit (BD Biosciences, San Jose, CA, USA). All groups of cells were strictly treated under manual processing and analyzed using a Beckman Coulter Cytomics FC500 flow cytometer (Beckman Coulter, Inc., Brea, CA, USA). The data were analyzed by EXPO32 ADC analysis software.

Cell cycle analysis was performed using the standard method with some modifications. Cells were fixed overnight with $75 \%$ ethanol at $4^{\circ} \mathrm{C}$. The following day, the fixed cells were washed with phosphate-buffered saline (PBS). Then, the cells were suspended with $200 \mu \mathrm{l}$ RNase A at $37^{\circ} \mathrm{C}$ for $10 \mathrm{~min}$, followed by the addition of $250 \mu \mathrm{l}$ propidium iodide (PI) $(100 \mu \mathrm{g} / \mathrm{ml})$ to stain the DNA of cells in the dark for $15 \mathrm{~min}$. Finally, the cell cycle was analyzed with a Beckman Coulter Cytomics FC 500 flow cytometer, and the data was analyzed using MultiCycle AV for Windows (version 295) software.

Real-time PCR analysis. Total RNA from treated cells was extracted using TRIzol and was used to synthesize cDNA using PrimeScript RT reagent kit (both from Takara, Dalian, China) according to the manufacturer's instructions. Then, real-time PCR was carried out using PowerUp SYBR-Green Master Mix (Life Technologies, Thermo Fisher Scientific). The reaction was conducted using the following parameters: $95^{\circ} \mathrm{C}$ for $30 \mathrm{sec}, 40$ cycles at $95^{\circ} \mathrm{C}$ for $5 \mathrm{sec}$ and $60^{\circ} \mathrm{C}$ for $30 \mathrm{sec}$. Internal control and primers for real-time PCR were obtained from the reference. Real-time PCR primers were synthesized by SBS Genentech Co. Ltd. (Shanghai, China). The specific primers for $\mathrm{P} 65, \mathrm{I} \kappa \mathrm{B}, \mathrm{c}-\mathrm{Met}$ and the reference gene ( $\beta$-actin) arelistedasfollows:p65forward,5'-ACAACCCCTTCCAAGTT CCT-3' and reverse, 5'-TGGTCCCGTGAAATACACCT-3'; I $\kappa$ B forward, 5'-TGAGGACCAGCAGTGTCTTG-3' and reverse, 5'-CATCGTTGATCACAAGTCGG-3'; c-Met forward, 5'-CATCTCAGAACGGTTCATGCC-3' and reverse, 5'-TGCACAATCAGGCTACTGGG-3'; $\beta$-actin forward, 5'-GCTACAGCTTCACCACCACAG-3' and reverse, 5'-GGT CTTTACGGATGTCAACGTC-3'. The experiments were repeated at least three times and the data were analyzed using $2^{-\Delta \Delta \mathrm{Ct}}$.

Western blot analysis. MCF-7 and MDA-MB-231 cells were treated with different concentrations of Huaier extract (4 and $8 \mathrm{mg} / \mathrm{ml})$ and/or paclitaxel $(0.01$ and $0.1 \mu \mathrm{g} / \mathrm{ml})$ for $48 \mathrm{~h}$. The cells were lysed and total protein was separated using $10 \%$ sodium dodecyl sulfate-polyacrylamide gel 
electrophoresis (SDS-PAGE) and transferred (300 mA, 2 h) onto polyvinylidene fluoride (PVDF) membranes. After blotting with 5\% non-fat milk, the membranes were incubated with primary antibodies (anti p65 1:5,000, anti p-p65 1:1,000, anti I $\mathrm{KB} \alpha 1: 1,000$, anti c-Met 1:1,000, $\beta$-actin 1:5,000) at $4^{\circ} \mathrm{C}$ overnight. Then, the membranes were washed using Trisbuffered saline with Tween-20 (TBS-T) buffer and incubated with a secondary horseradish peroxidase (HRP)-labeled antirabbit antibody at room temperature for $1 \mathrm{~h}$. Subsequently, the membranes were washed again with TBS-T buffer three times (10 min each time). The target proteins were visualized with a chemiluminescence system (Gene Company Ltd., Shanghai, China) and normalized to $\beta$-actin from the same membrane.

Xenograft tumorigenicity assay. MCF-7 and MDA-MB-231 cells $\left(5 \times 10^{6}\right.$ in $\left.0.1 \mathrm{ml} \mathrm{PBS}\right)$ were subcutaneously injected into four week old female nude mice. Treatments were started at the second week after injection. The mice were randomly assigned to control (double-distilled water), Huaier extract, paclitaxel or combined treatment groups. The dose of Huaier extract was $250 \mathrm{mg} / \mathrm{ml}$ and paclitaxel was $10 \mathrm{mg} / \mathrm{kg}$. The Huaier group was administered $50 \mathrm{mg}$ of Huaier extract by gavage once every two days, while paclitaxel was administered by intraperitoneal injection (IP) once a week or both were administered in the combined treatment group. Tumor growth was assessed every week and the tumor volume was calculated using the formula: $0.5 \mathrm{x}$ (length $\mathrm{x}$ width $\left.{ }^{2}\right)$. After six weeks, the mice were sacrificed and the xenografted tumors were removed for flow cytometric and western blot analyses.

Statistical analysis. Statistical analyses were performed with SPSS for Windows 21.0 (SPSS, Inc., Chicago, IL, USA). Student's t-tests and one-way ANOVA were performed to determine statistical significance. All data are presented as mean \pm standard error of the mean (SEM) of three experiments, and $\mathrm{P}<0.05$ was considered statistically significant.

\section{Results}

Combination of Huaier extract and paclitaxel exhibits a more effective inhibitory effect on cell proliferation compared with monotherapies. As shown in Fig. 1A and B, Huaier extract reduced the viability of MCF-7 and MDA-MB-231 cells in a time- and concentration-dependent manner. Compared with the control group, 10 and $16 \mathrm{mg} / \mathrm{ml}$ of Huaier extract significantly decreased cell viability in both cell lines at $24 \mathrm{~h}(\mathrm{P}<0.01)$. At $48 \mathrm{~h}$, the dosing $>4 \mathrm{mg} / \mathrm{ml}$ of Huaier extract significantly reduced the cell viability in both cell lines $(\mathrm{P}<0.01)$. We observed that the proliferation of MCF-7 and MDA-MB-231 cells was significantly inhibited by paclitaxel treatment in a time- and dose-dependent manner (Fig. 1C and D). At 48 h, cell viability was significantly decreased by paclitaxel treatment as low as $0.01 \mu \mathrm{g} / \mathrm{ml}(\mathrm{P}<0.05)$. The combined therapies sharply decreased the viability of both MCF-7 and MDA-MB231 cells, and the extent of reduced cell viability by combined therapies was significantly greater than the monotherapies of Huaier extract or paclitaxel treatment (Fig. 1E and F). Compared with the $0.1 \mu \mathrm{g} / \mathrm{ml}$ of paclitaxel treatment alone, the inhibition rate of cell viability in the combined treatments
(H8P0.1) was $1.382 \pm 0.161$ times in the MCF-7 cells, and $2.83 \pm 0.751$ times in the MDA-MB-231 cells (Fig. 1G and H). In order to establish a synergistic mode of action between Huaier and paclitaxel, we performed an isobolometric analysis. The results revealed that the point was on the left. This suggested that the combined action was supra-additive in both cell lines (Fig. 1I and J).

Huaier extract combined with paclitaxel to induce apoptosis in MCF-7 and MDA-MB-231 cells. The four quadrants of the apoptosis results: upper left represents cell debris, upper right represents late-stage apoptotic, lower left represents living and lower right represents early-stage apoptotic cells. Compared with the control group, Huaier extract (H4P0 and H8P0) significantly increased cell apoptosis in MCF-7 and MDA-MB-231 cells, and $8 \mathrm{mg} / \mathrm{ml}$ of Huaier extract revealed a more significant effect on cell apoptosis than $4 \mathrm{mg} / \mathrm{ml}$ Huaier extract (Fig. 2 A and B; P<0.001). Similar to Huaier extract treatment, paclitaxel treatment (H0P0.01 and HOP0.1) significantly induced cell apoptosis in MCF-7 and MDA-MB-231 cells, and $0.1 \mu \mathrm{g} / \mathrm{ml}$ of paclitaxel exhibited a more significant effect, particularly in the increase of earlystage apoptosis (Fig. 2A and B; $\mathrm{P}<0.001$ ). The combined treatments of Huaier extract and paclitaxel revealed a more significant effect on cell apoptosis than the monotherapies (Fig. 2A and B). Compared with paclitaxel treatment (H0P0.01 and H0P0.1) alone, the apoptosis rate in the combined therapy group (H4P0.01 and H8P0.1) increased by 2.139 and 1.431 times, respectively, in MCF-7 cells $(\mathrm{P}<0.001)$. Similarly, in MDA-MB-231 cells, the apoptosis rate of the combined therapy group (H4P0.01 and H8P0.1) increased by $1.131(\mathrm{P}<0.05)$ and 2.245 times $(\mathrm{P}<0.001)$, respectively, compared with paclitaxel treatment alone (H0P0.01 and HOP0.1).

Huaier extract synergizes with paclitaxel to induce cell cycle arrest in MCF-7 and MDA-MB-231 cells. After being exposed to Huaier extract for $48 \mathrm{~h}$, the percentage of cells in the G0/G1 phase significantly increased in both MCF-7 cells (from $41.268 \pm 0.11$ to $55.704 \pm 0.45 \%$; $\mathrm{P}<0.001$ ) and MDA-MB-231 cells (from $35.026 \pm 0.23$ to $55.659 \pm 1.54 \%$; $\mathrm{P}=0.001$ ), while the percentage of cells in the $\mathrm{S}$ phase was decreased (Fig. 3A and B). Moreover, a higher concentration of Huaier extract (H8P0) exhibited a stronger effect on cell cycle arrest in the G0/G1 phase in both cell lines compared with the lower dose (H4P0). Notably, paclitaxel treatment (H0P0.01 and H0P0.1) also significantly induced cell cycle arrest in both cell lines, but cell cycle arrest was observed in the $\mathrm{G} 2 / \mathrm{M}$ phase (Fig. 3A and B; $\mathrm{P}<0.001$ ). Similar to Huaier extract treatment, paclitaxel treatment reduced the percentage of MCF-7 and MDA-MB-231 cells in the S phase $(\mathrm{P}<0.001)$. Furthermore, we analyzed the cell cycle in MCF-7 and MDA-MB-231 cells after combined therapies and found significant arrest in both $\mathrm{G} 0 / \mathrm{G} 1$ and $\mathrm{G} 2 / \mathrm{M}$ phases while the proportion of $\mathrm{S}$ phase was sharply decreased $(\mathrm{P}<0.001)$.

Huaier extract and paclitaxel target p65, I $\kappa \mathrm{B} \alpha$ and $c$-Met in MCF-7 and MDA-MB-231 cells. c-Met plays an important role in cell proliferation, invasion and chemoresistance. The phosphorylation of c-Met activates multiple downstream signaling 

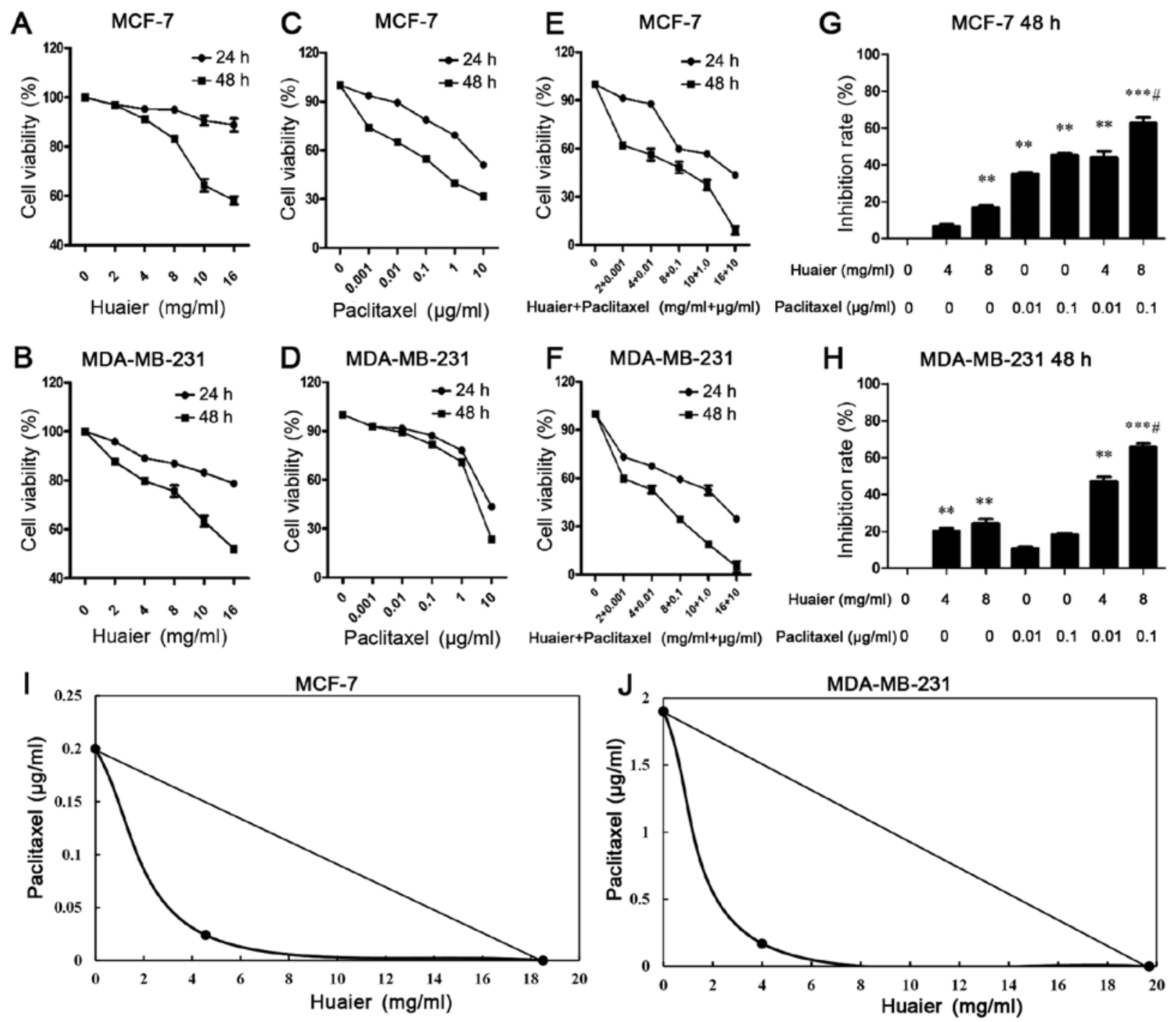

Figure 1. Combined treatments inhibit cell proliferation more significantly than monotherapies. Both (A and B) Huaier and (C and D) paclitaxel inhibited cell viability in a dose- and time-dependent manner. (E and F) Combined treatments significantly inhibited cell viability more than monotherapies in both cell lines. The inhibition rates of (G) MCF-7 and (H) MDA-MB-231 cells in the H8P0.1 group were higher than that in the H0P0.1. (I and J) The results of isobolometric analysis. The point was on the left, indicating that the combined action was supra-additive in both cell lines. The data were analyzed by one-way ANOVA $(\mathrm{n}=3)$, and $\mathrm{P}<0.05$ was statistically significant $\left({ }^{* *} \mathrm{P}<0.01,{ }^{* * * *} \mathrm{P}<0.001\right.$ vs. control group; ${ }^{*} \mathrm{P}<0.05$, vs. paclitaxel alone).

pathways, including Ras/MAPK, PI3K/Akt and NF-кB. Thus, we wanted to detect whether Huaier and combined treatment mediated c-Met expression. As shown in Fig. 4A and B and G, after being treated with Huaier extract (H4P0 and H8P0) for $48 \mathrm{~h}$, the expression of $\mathrm{p} 65$ and c-Met at the mRNA and protein levels was significantly decreased, while the expression of I $\kappa \mathrm{B} \alpha$ was significantly increased after treatment with H8P0 for $48 \mathrm{~h}(\mathrm{P}<0.01)$. Therefore, Huaier extract suppressed the NF- $\kappa \mathrm{B} / \mathrm{I} \kappa \mathrm{B} \alpha$ pathway. In contrast to the Huaier extract treatment, paclitaxel treatment (H0P0.01 and HOP0.1) for $48 \mathrm{~h}$ significantly increased the expression of $\mathrm{p} 65$ at the mRNA and protein levels in MCF-7 and MDA-MB-231 cells $(\mathrm{P}<0.05)$, while the expression of $\mathrm{I} \kappa \mathrm{B} \alpha$ and $\mathrm{c}-\mathrm{Met}$ at the mRNA and protein levels was significantly reduced (Fig. 4C, D and G). These results implied that paclitaxel activates the NF- $\kappa B$ pathway. We also examined the expression of $\mathrm{p} 65, \mathrm{I} \kappa \mathrm{B} \alpha$ and c-Met in MCF-7 and MDA-MB-231 cells after combined treatments with Huaier extract and paclitaxel (Fig. 4E, F and G). The combined treatments $(\mathrm{H} 4+\mathrm{P} 0.01$ and $\mathrm{H} 8+\mathrm{P} 0.1)$ significantly decreased the expression of $\mathrm{p} 65$ and c-Met at the mRNA and protein levels, while the expression of I $\mathrm{K} \mathrm{B} \alpha \mathrm{mRNA}$ and protein was significantly increased in both cell lines after combined treatments $(\mathrm{P}<0.05)$. These results were similar but more significant than those of the Huaier extract treatment alone.

\section{Combined Huaier extract and paclitaxel treatments inhibit} tumor growth in a xenograft model. To ascertain the inhibitory effect of Huaier extract and paclitaxel on breast cancer cells, we examined the antitumor effect of Huaier extract, paclitaxel and combined treatment in nude mice. Compared with the control group $\left(825.8 \pm 33.7 \mathrm{~mm}^{3}\right)$, the tumor volume in the Huaier $\left(367.3 \pm 22.1 \mathrm{~mm}^{3} ; \mathrm{P}<0.05\right)$, paclitaxel $\left(223.9 \pm 28.2 \mathrm{~mm}^{3} ; \mathrm{P}<0.01\right)$ and combined treatment group $\left(158.1 \pm 25.2 \mathrm{~mm}^{3} ; \mathrm{P}<0.01\right)$ was significantly smaller in MCF-7 xenografted tumors (Fig. 5A). However, there was no significant difference in the volume between the combined group and paclitaxel group $(\mathrm{P}=0.144)$. Similar results were observed in the MDA-MB-231 xenografted tumors (Fig. 5B), but the 
A
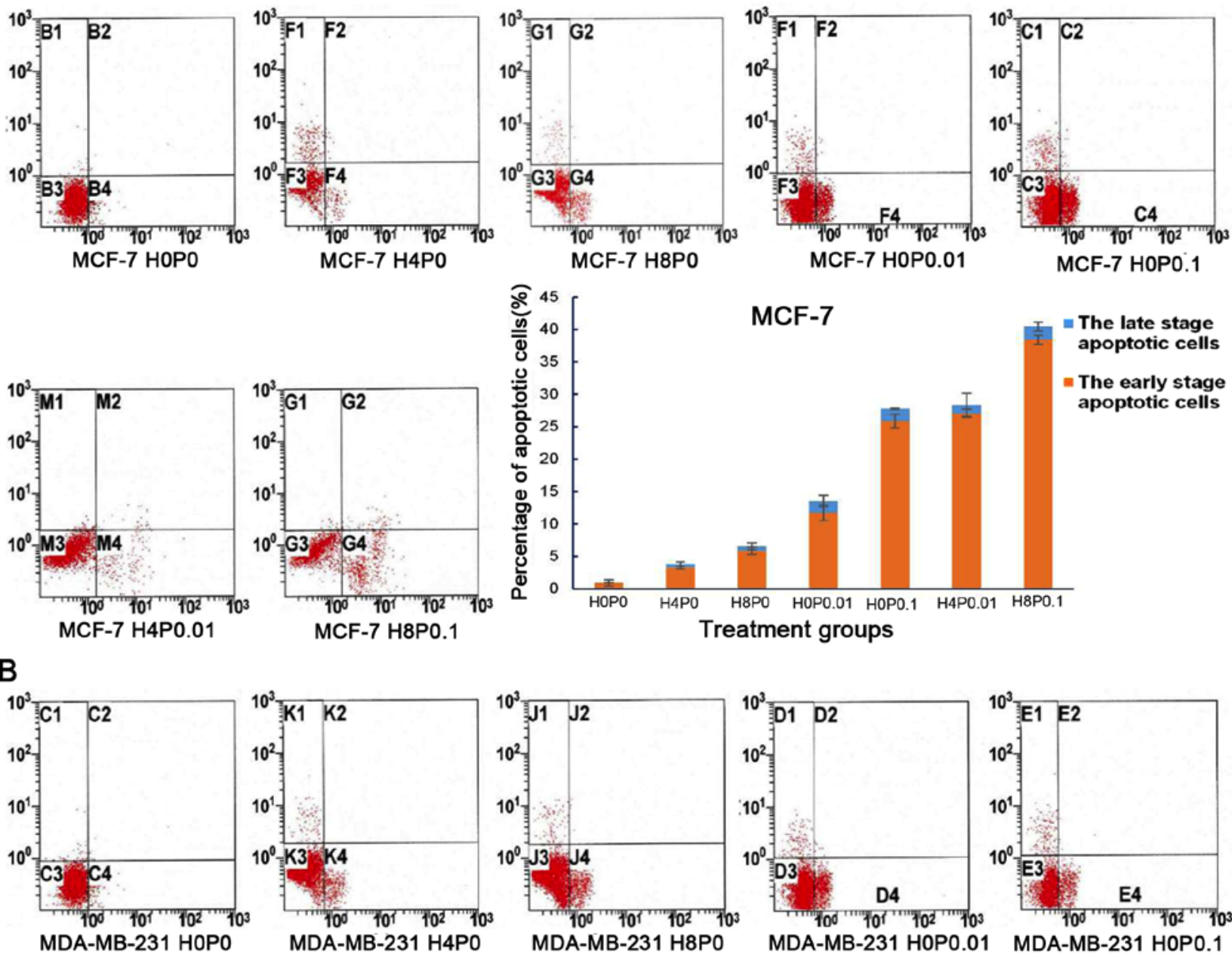

MCF-7
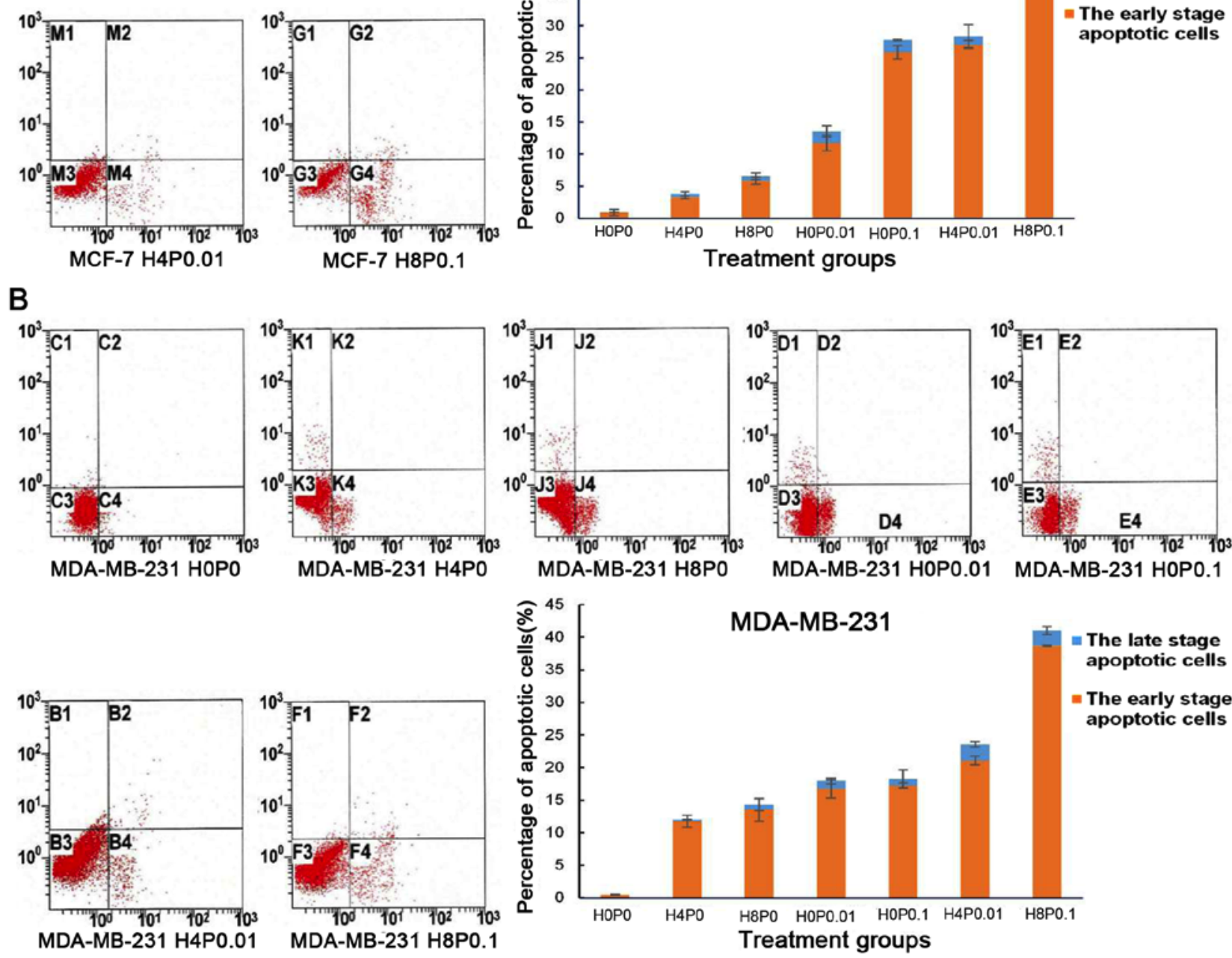

Figure 2. Huaier extract combined with paclitaxel induces apoptosis in MCF-7 and MDA-MB-231 cells. The four quadrants of the results: upper left represents cell debris, upper right represents late-stage apoptotic, lower left represents living and lower right represents early-stage apoptotic cells. (A) The apoptosis rates of MCF-7 cells treated with 4 and $8 \mathrm{mg} / \mathrm{ml}$ Huaier extract were $4.30 \pm 0.030 \%\left({ }^{* *} \mathrm{P}<0.01\right)$ and $7.57 \pm 0.012 \%(* \mathrm{P}<0.001)$ compared with the untreated group $0.94 \pm 0.057 \%$. The apoptosis rates of MCF-7 cells treated with 0.01 and $0.1 \mu \mathrm{g} / \mathrm{ml}$ paclitaxel were $13.54 \pm 0.89 \%\left({ }^{* * *} \mathrm{P}<0.001\right)$ and $28.67 \pm 0.12 \%\left({ }^{* * *} \mathrm{P}<0.001\right)$ compared with the untreated group. The apoptosis rates of MCF-7 cells treated with H4P0.01 and H8P0.1 were $28.97 \pm 1.78 \%(* * * \mathrm{P}<0.001)$ and $41.03 \pm 0.69 \%$ $\left({ }^{* * *} \mathrm{P}<0.001\right)$ respectively, compared with the untreated MCF-7 group. (B) The apoptosis in MDA-MB-231 cells was induced by the same treatment as in MCF-7 cells. The apoptosis rates of MDA-MB-231 cells treated with 4 and $8 \mathrm{mg} / \mathrm{ml}$ Huaier extract were $12.28 \pm 0.100 \%\left({ }^{* * * *} \mathrm{P}<0.001\right)$ and $14.29 \pm 0.045 \%\left({ }^{* * *} \mathrm{P}<0.001\right)$ respectively, compared with the untreated group. The apoptosis rates of MDA-MB-231 cells treated with 0.01 and $0.1 \mu \mathrm{g} / \mathrm{ml}$ paclitaxel were $14.97 \pm 0.54 \%$ $\left.{ }^{* * * *} \mathrm{P}<0.001\right)$ and $18.27 \pm 1.39 \%\left({ }^{* * *} \mathrm{P}<0.001\right)$ compared with the untreated group. The apoptosis rates of MDA-MB-231 cells treated with H4P0.01 and H8P0.1 were $23.56 \pm 0.40 \%\left({ }^{* * *} \mathrm{P}<0.001\right)$ and $41.02 \pm 0.62 \%\left({ }^{* * *} \mathrm{P}<0.001\right)$ respectively, compared with the untreated group. The combined therapies of Huaier extract and paclitaxel (H4P0.01 and H8P0.1) induced the most apoptotic effect in (A) MCF-7 and (B) MDA-MB-231 cells. The data were analyzed by one-way ANOVA $(n=3)$.

tumor volume in the combined group was smaller than that in the paclitaxel group $(\mathrm{P}<0.05)$. After the mice were sacrificed, we assessed the tumor weight (Fig. 5C and D). The tumor weight in each group was consistent with that of tumor volume in both cell lines $(\mathrm{P}<0.05)$. Moreover, compared with the paclitaxel group, the tumor weight in the combined group was lighter in both xenografted tumors $(\mathrm{P}<0.05)$. To examine the antitumor mechanisms of the Huaier extract, paclitaxel and 

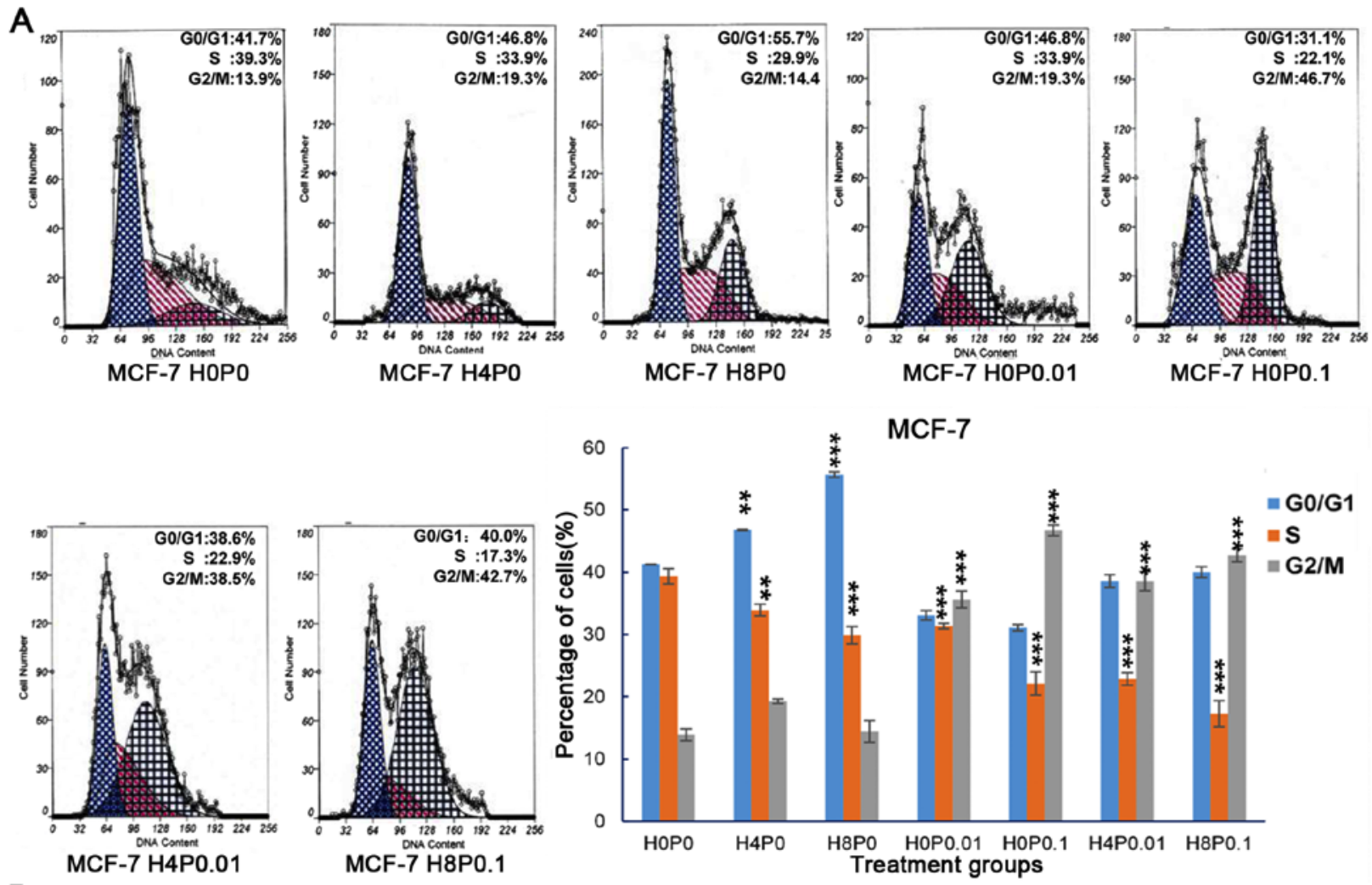

B
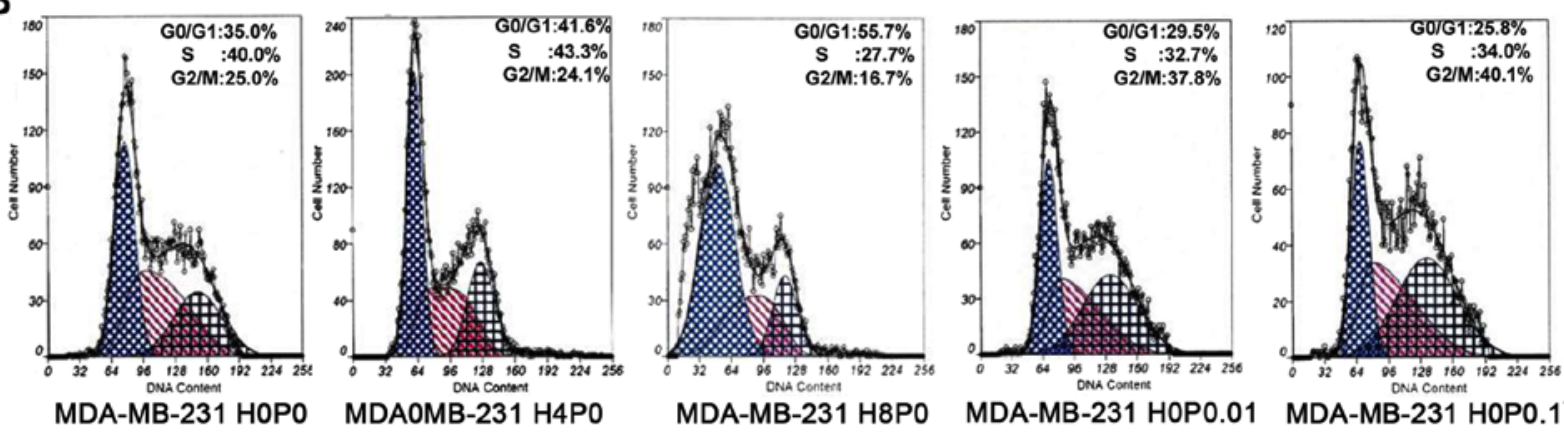

MDA-MB-231 HOP0.01

MDA-MB-231 HOP0.1
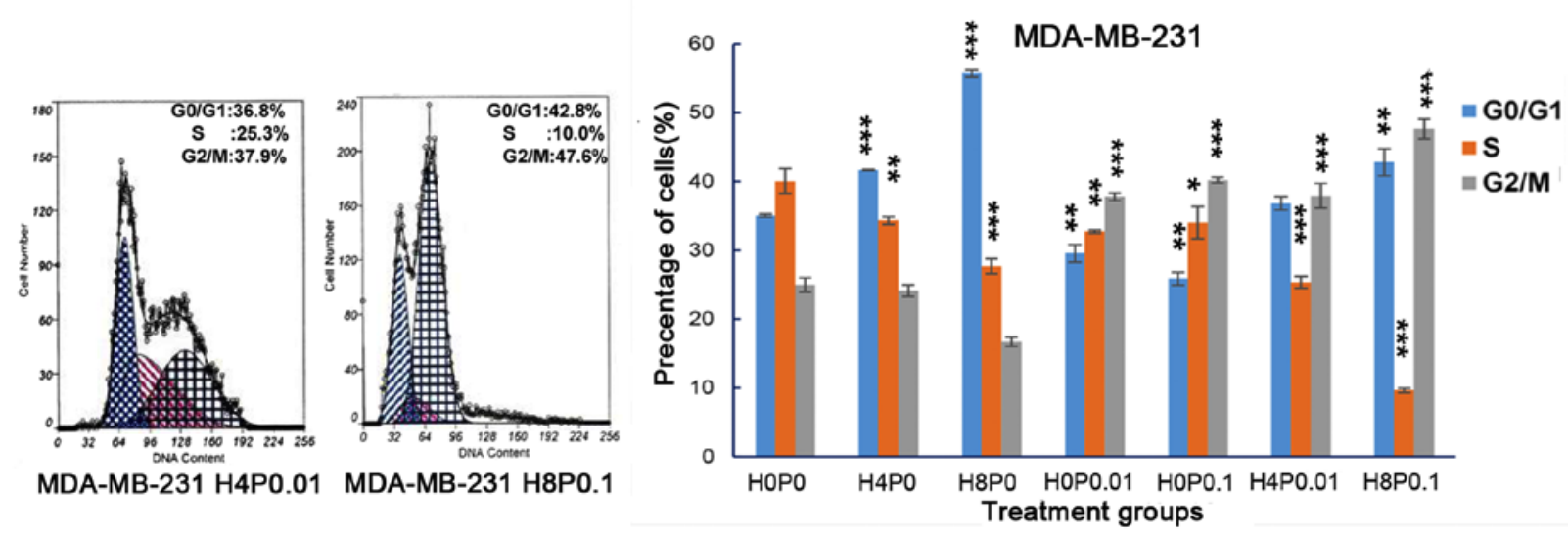

Figure 3. Huaier extract synergizes with paclitaxel to induce cell cycle arrest in MCF-7 and MDA-MB-231 cells. Huaier extract (4 or $8 \mathrm{mg} / \mathrm{ml})$ induced G0/ G1 arrest and decreased the S phase in (A) MCF-7 and (B) MDA-MB-231 cells. Paclitaxel treatment ( 0.01 or $0.1 \mu \mathrm{g} / \mathrm{ml})$ induced G2/M arrest and decreased the S phase in (A) MCF-7 and (B) MDA-MB-231 cells. Combined treatment induced G0/G1 and G2/M arrest in MCF-7 and MDA-MB-231 cells, however the proportion of $\mathrm{S}$ phase cells was decreased. The data are presented as the mean $\pm \mathrm{SD}$ of three separate experiments $\left({ }^{*} \mathrm{P}<0.05,{ }^{* *} \mathrm{P}<0.01,{ }^{* * *} \mathrm{P}<0.001 \mathrm{vs}\right.$. the control group).

the combined treatment in vivo, we analyzed the apoptosis and the expression of $\mathrm{p} 65$ and $\mathrm{I} \kappa \mathrm{B} \alpha$ in xenografted tumors. As shown in Fig. 5E and F, the combined treatments caused the most significant apoptosis compared to the control and monotherapy groups. Furthermore, combined treatment significantly decreased the expression of p65 and c-Met, but increased IкB $\alpha$ expression in xenografted tumors compared with those from monotherapies (Fig. 5G and $\mathrm{H}$ ). 
A

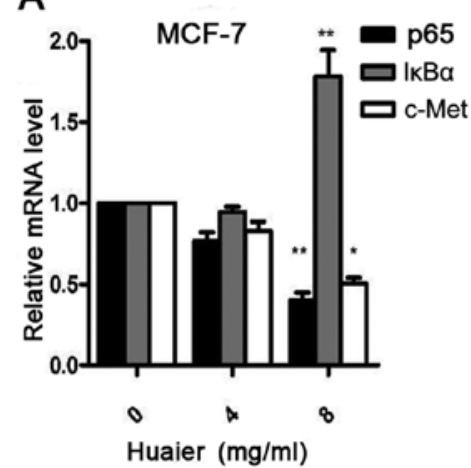

B

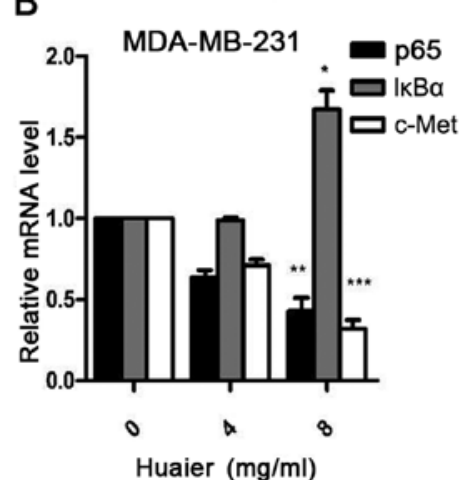

C

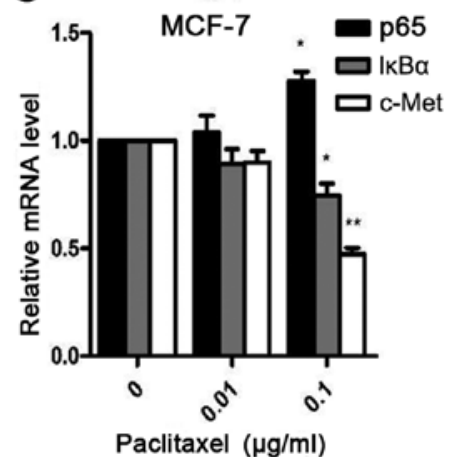

D

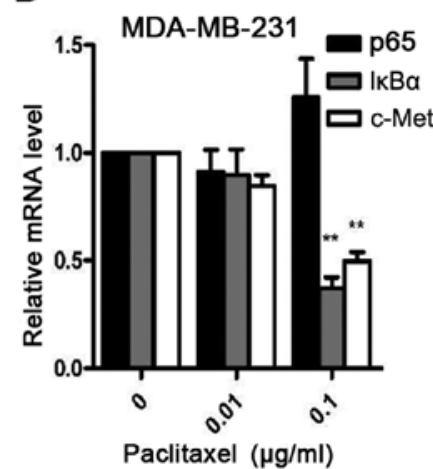

E

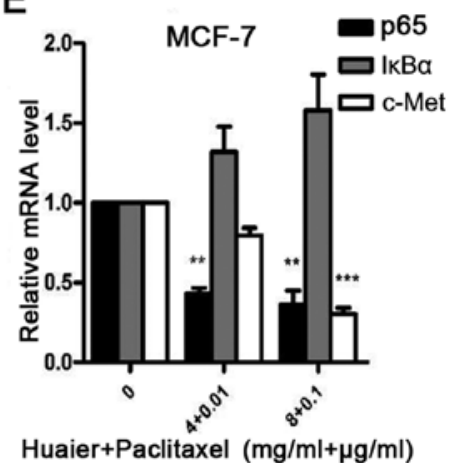

F

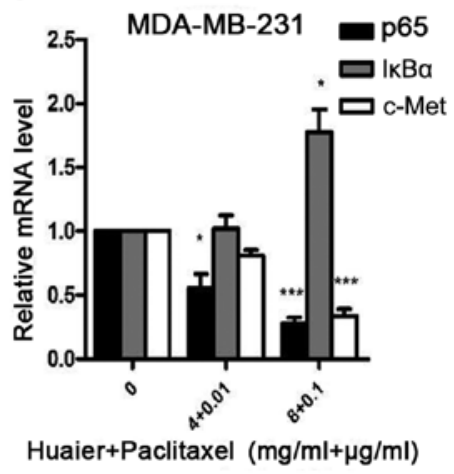

G

MCF-7

MDA-MB-231

\begin{tabular}{|c|c|c|c|c|c|c|c|c|c|c|c|c|c|c|}
\hline Paclitaxel $(\mu \mathrm{g}$ & /ml) 0 & 0 & 0 & 0.01 & 0.1 & 0.01 & 0.1 & 0 & 0 & 0 & 0.01 & 0.1 & 0.01 & 0.1 \\
\hline Huaier (mg/ & (ml) 0 & 4 & 8 & 0 & 0 & 4 & 8 & 0 & 4 & 8 & 0 & 0 & 4 & 8 \\
\hline p65 & $\longrightarrow$ & $\longrightarrow$ & & - & $\longrightarrow$ & - & & $=$ & - & $\infty$ & $\longrightarrow$ & 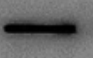 & $\longrightarrow$ & $\longrightarrow$ \\
\hline p-p65 & - & - & - & - & - & - & - & - & - & - & - & - & - & - \\
\hline IKBa & - & - & - & - & - & - & $\longrightarrow$ & - & - & - & - & - & - & $\longrightarrow$ \\
\hline c-Met & $=$ & $-\infty$ & - & - & - & - & $-\infty$ & - & & in & - & $\longrightarrow$ & $\longrightarrow$ & \\
\hline$\beta$-actin & & & & - & - & & 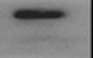 & & & & & & & \\
\hline
\end{tabular}

Figure 4. Huaier extract and paclitaxel target p65, IкB $\alpha$ and c-Met in MCF-7 and MDA-MB-231 cells. Huaier extract mediated the expression of p65, IкB $\alpha$ and c-Met at the mRNA levels in (A) MCF-7 and (B) MDA-MB-231 cells. Paclitaxel treatment mediated the expression of p65, IkB $\alpha$ and c-Met at the mRNA levels in (C) MCF-7 and (D) MDA-MB-231 cells. The effect of the combined therapies on the expression of p65, IкB $\alpha$ and c-Met at the mRNA levels in (E) MCF-7 and (F) MDA-MB-231 cells. (G) The protein expression levels of p65, IкB $\alpha$ and c-Met were altered in line with the mRNA expression level. The data are presented as the mean $\pm \mathrm{SD}$ of three separate experiments $\left({ }^{*} \mathrm{P}<0.05,{ }^{* *} \mathrm{P}<0.01,{ }^{* * *} \mathrm{P}<0.001\right.$ vs. the control group).

\section{Discussion}

Breast cancer, as a highly heterogeneous tumor, is significantly different in pathological type, molecular classification and prognosis. Estrogen receptor-positive breast cancer accounts for $\sim 70 \%$ of breast cancer and triple-negative breast cancer (TNBC) accounts for $\sim 10-20 \%$ (28). Although ER-positive breast cancer patients can benefit from endocrine therapy, chemotherapy is still an important systemic therapy after surgery for preventing recurrent and metastasis. Chemotherapy is the only treatment for TNBC presently, since TNBC is invasive, recurs and metastasizes easily and thus TNBC cannot benefit from endocrine and target therapy.
Recently, traditional Chinese medicines (TCMs) have been considered as anticancer drugs for their ability to kill cancer cells, and reduce the side-effects of chemotherapy. Huaier extract has been found to not only have an antitumor effect, but also enhance the sensitivity of cancer cells to chemotherapy drugs and improve immunity and long-term prognosis in cancer patients $(29,30)$. Bao et al (18) found that the Huaier extract inhibited the proliferation of human hepatocellular carcinoma Hep-G2 cells and induced cell apoptosis in a concentration-dependent manner. In the present study, after treating MCF-7 and MDA-MB-231 cells with Huaier extract for 24 and $48 \mathrm{~h}$, we found that Huaier extract inhibited cell proliferation, reduced cell viability 
A

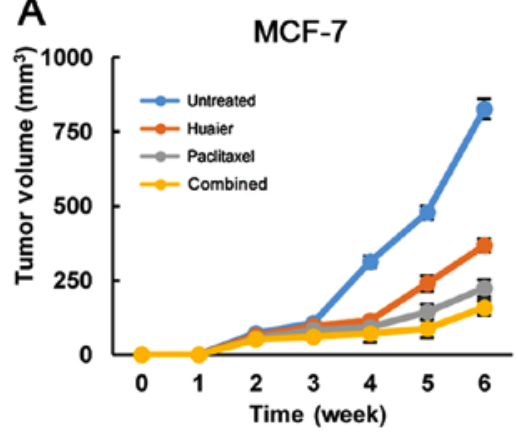

C

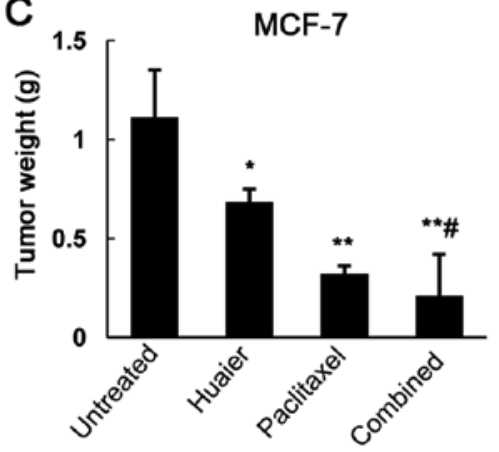

B

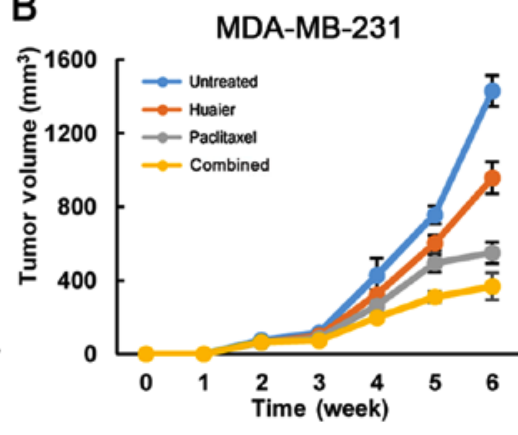

D

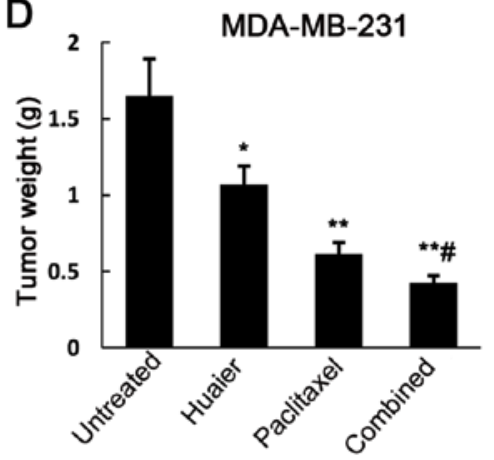

G

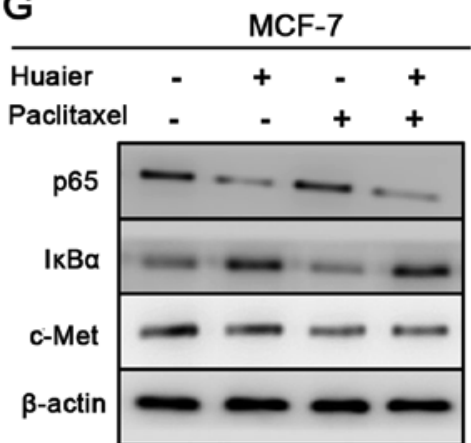

$\mathrm{H}$

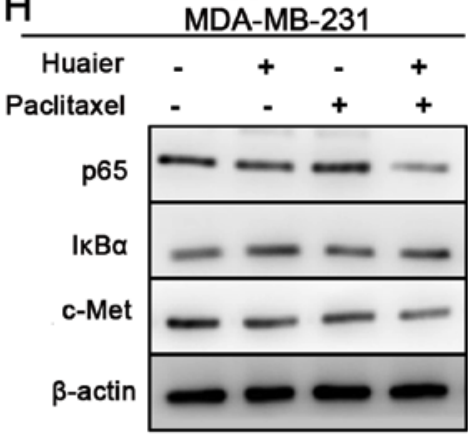

$\mathrm{E}$
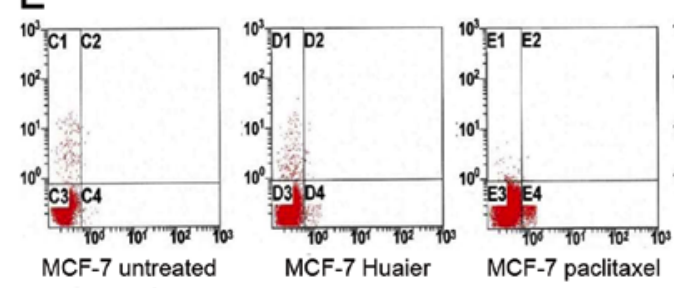

MCF-7 paclitaxel
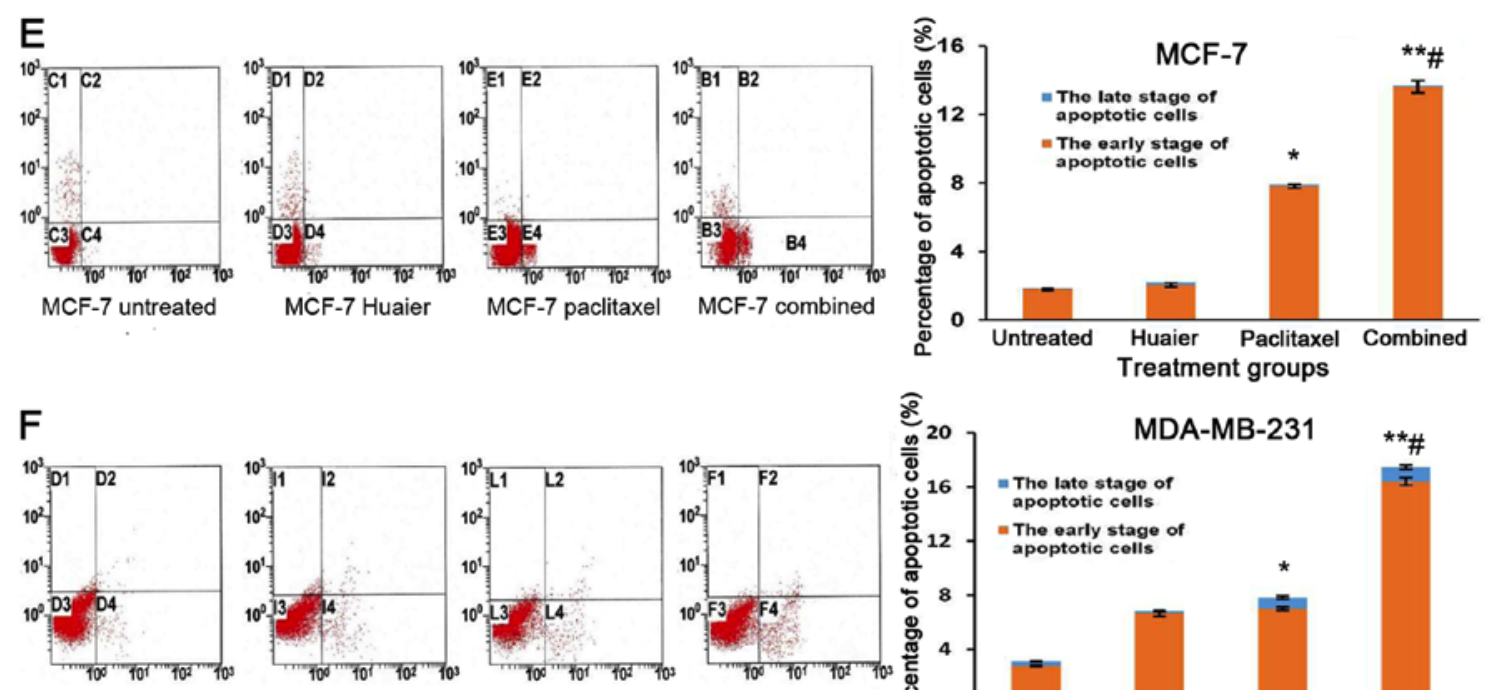

MDA-MB-231 untreated

MDA-MB-231 Huaier MDA-MB-231 paclitaxel MDA-MB-231 combined

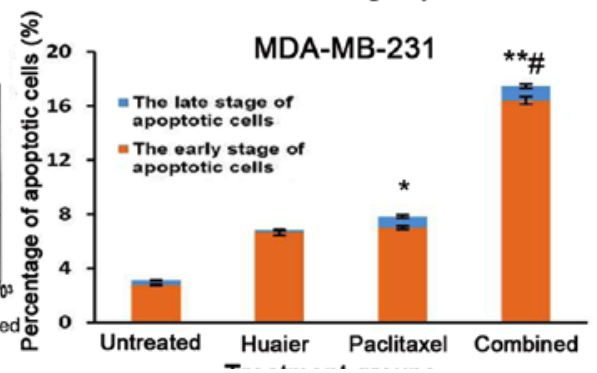

Figure 5. Huaier extract enhances the paclitaxel treatment efficacy in a xenograft model. Mice were sacrificed six weeks after being injected with either Huaier extract or paclitaxel or a combination of both. (A and B) The growth curves of xenograft tumors from MCF-7 and MDA-MB-231 cells at different time-points. In both cell lines, compared with the control group, the tumor volume in the Huaier $(\mathrm{P}<0.05)$, paclitaxel $(\mathrm{P}<0.01)$ and combined treatment groups $(\mathrm{P}<0.01)$ was significantly smaller. (C and D) The tumor weight from the MCF-7 and MDA-MB-231 cells in different groups. The tumor weight of the combined treatment group was significantly lower than that of the control group $(\mathrm{P}<0.01)$. (E and F) Flow cytometric analysis of apoptosis in MCF-7 and MDA-MB-231 xenograft tumors. The apoptosis rates of MCF-7 xenograft tumors treated with Huaier, paclitaxel and a combination of both were $(2.05 \pm 0.18 \%)$, $(7.82 \pm 0.05 \%)^{*}$ and $(13.62 \pm 0.09 \%)^{* * * \#}$ compared with the untreated group $(1.94 \pm 0.03 \%)$. The apoptosis rates of MDA-MB-231 xenograft tumors treated with Huaier, paclitaxel and a combination of both were $(6.63 \pm 0.21 \%),(6.92 \pm 0.83 \%)^{*}$ and $(16.40 \pm 1.06 \%)^{* * * t}$ compared with the untreated group $(2.78 \pm 0.33 \%)$. $(\mathrm{G}$ and $\mathrm{H}) \mathrm{Combination}$ treatment decreased the level of p65 and increased I $\kappa \mathrm{B} \alpha$. The data are presented as the mean $\pm \mathrm{SD}$ of three separate experiments $\left({ }^{*} \mathrm{P}<0.05,{ }^{* *} \mathrm{P}<0.01,{ }^{* * *} \mathrm{P}<0.001\right.$ vs. the control group; ${ }^{\#} \mathrm{P}<0.05$ vs. the paclitaxel group).

and promoted cell apoptosis in a time- and dose-dependent manner, results which were consistent with a study from Zhang et al (14). We also found that Huaier extract could induce cell cycle arrest in the G0/G1 phase, which was in line with a study by Qi et al (21). A previous study demonstrated that paclitaxel treatment caused cell cycle arrest in the G2/M phase, inhibited mitotic progression and induced apoptotic cell death (31). In the present study, we found that combined therapies of Huaier extract and paclitaxel treatments in breast cancer cells induced cell cycle arrest in the G0/G1 and G2/M phases, but reduced the percentage of cells in the $\mathrm{S}$ phase. These results revealed that both Huaier extract and paclitaxel treatments inhibited cell proliferation activity and induced cell apoptosis in breast cancer cells, and the combined therapies achieved the most effective efficacy. 
Our research also studied the relationship between the anticancer effect of paclitaxel and the NF- $\kappa \mathrm{B}$ pathway. Current studies have suggested that paclitaxel functions by binding to tubulin, promoting the formation of stable microtubules and inhibiting microtubule depolymerization. Thus, paclitaxel interferes with the normal function of mitotic spindle formation, arrests the cell cycle in the $\mathrm{G} 2 / \mathrm{M}$ phase and induces cell death in cancer (32). Our results revealed that paclitaxel reduced $\mathrm{I} \kappa \mathrm{B} \alpha$ expression, but increased p 65 expression. As the inhibitory protein of $\mathrm{NF}-\kappa \mathrm{B}$, the reduction of $\mathrm{I} \kappa \mathrm{B} \alpha$ expression was associated with $\mathrm{NF}-\kappa \mathrm{B}$ activation. Similar results were also observed in a study in which paclitaxel induced the degradation of the I $\kappa \mathrm{B} \alpha$ protein, which in turn activated NF- $\kappa \mathrm{B}$ and induced cell apoptosis (33). Bava et al (34) reported that paclitaxel treatment after 30 min may lead to the translocation of $N F-\kappa B$ into the nucleus of HeLa cells. NF- $\kappa$ B activation plays an important role in the resistance to cytotoxic agents (such as doxorubicin), microtubule disrupting agents (such as paclitaxel) and 5-fluorouracil (27,31). Our data indicated that paclitaxel treatment for $48 \mathrm{~h}$ may induce drug resistance via $\mathrm{NF}-\kappa \mathrm{B}$ activation.

In a previous study, the combination of Huaier extract with chemotherapy drugs promoted tumor cell apoptosis and improved sensitivity of tumor cells to chemotherapy drugs (15), but the mechanism is still not clear. Zhang et al (35) reported that Huaier increased the sensitivity of MCF-7/A breast cancer cells to adriamycin (ADM) which was related to the decrease in the expression of drug resistant gene MDR-1. Another study revealed that Huaier extract synergized with tamoxifen (TAM) to increase apoptosis and G0/G1 arrest in ER-positive breast cancer cells (21). However, in the actively proliferative cancer cells, the proportion of G0/G1 and S phase cells was much higher than the proportion of G2/M phase cells. Paclitaxel mainly induced cell cycle arrest in the G2/M phase, while Huaier extract caused cell cycle arrest in the G0/G1 phase. Therefore, paclitaxel and Huaier complemented each other and the anticancer effect produced from their combination treatment was significantly improved. Moreover, the inhibition of NF- $\kappa \mathrm{B}$ (p65) was more effective after combined therapies. A previous study suggested that the inhibition of $N F-\kappa B$ can improve tumor cell sensitivity to chemotherapy drugs (36). Our results revealed that compared with monotherapies, the combined therapies increased cell cycle arrest in the G0/G1 and G2/M phases, more significantly promoted cell apoptosis, inhibited NF- $\mathrm{NB}$ and enhanced antitumor efficacy.

The encoding product of proto-oncogene $c$-met is the hepatocyte growth factor receptor (also known as c-Met), which is a transmembrane tyrosine kinase. c-Met plays an important role in cell proliferation, invasion and angiogenesis (37). In breast cancer tissue particularly TNBC, c-Met was abnormally expressed (38). The phosphorylation of c-Met activated multiple downstream signaling pathways, including Ras/MAPK, PI3K/Akt and NF-кB (39). Activation of the PI3K/Akt pathway increased cell survival and inhibited apoptosis. Akt can regulate the NF- $\mathrm{B}$ pathway. In a future study we would like to further investigate the relationship between drug resistance reversion by Huaier and c-Met/Akt/NF- $\kappa \mathrm{B}$. In the present study, both the Huaier extract and paclitaxel inhibited the expression of c-Met, and their combination in a high-dose group revealed the most inhibitory effect on c-Met expression.
These results revealed that combined treatments may enhance the antitumor effect of paclitaxel therapy in breast cancer cells.

Our results demonstrated that Huaier-induced inhibition of the NF- $\kappa$ B pathway resulted in the suppression of cell proliferation and the promotion of apoptosis. Paclitaxel-induced $\mathrm{NF}-\kappa \mathrm{B}$ activation was associated with chemoresistance and a decreased antitumor effect. Huaier reversed the effect of paclitaxel on the activation of $\mathrm{NF}-\kappa \mathrm{B}$, and thus, suppressed cell proliferation and increased the antitumor effect. The $\mathrm{NF}-\kappa \mathrm{B}$ pathway may play an important role in the combined treatment. In future, further research into the molecular mechanisms and the proteins involved in the cell cycle and proliferation as well as resistance-associated genes regulated by $N F-\kappa B$ is warranted in order to obtain more valuable insights.

In summary, Huaier extract synergized with paclitaxel to suppress proliferation and increase apoptosis in ER-positive breast cancer cells and TNBC. The mechanisms were involved in inducing cell cycle arrest and cell apoptosis and inhibition of the NF- $\kappa \mathrm{B}$ pathway. Moreover, the combined treatments of Hauier extract and paclitaxel were more effective on antitumor activity than the monotherapies, which may increase the anticancer effect of breast cancer cells to paclitaxel therapy.

\section{Acknowledgements}

The present study was supported by the Hebei Province Natural Science Foundation (H2012206169).

\section{References}

1. Panieri E: Breast cancer screening in developing countries. Best Pract Res Clin Obstet Gynaecol 26: 283-290, 2012.

2. Ferlay J, Shin HR, Bray F, Forman D, Mathers C and Parkin DM: Estimates of worldwide burden of cancer in 2008: GLOBOCAN 2008. Int J Cancer 127: 2893-2917, 2010.

3. Fan L, Zheng Y, Yu KD, Liu GY, Wu J, Lu JS, Shen KW, Shen ZZ and Shao ZM: Breast cancer in a transitional society over 18 years: Trends and present status in Shanghai, China. Breast Cancer Res Treat 117: 409-416, 2009.

4. Kim YM, Tsoyi K, Jang HJ, Park EJ, Park SW, Kim HJ, Hwa JS and Chang $\mathrm{KC}$ : CKD712, a synthetic isoquinoline alkaloid, enhances the anti-cancer effects of paclitaxel in MDA-MB-231 cells through regulation of PTEN. Life Sci 112: 49-58, 2014.

5. Sonnenblick A, Eleyan F, Peretz T, Ospovat I, Merimsky O, Sella T, Peylan-Ramu N and Katz D: Gemcitabine in combination with paclitaxel for advanced soft-tissue sarcomas. Mol Clin Oncol 3: 829-832, 2015.

6. Wall ME, Wani MC and Taylor H: Plant antitumor agents, 27. Isolation, structure, and structure activity relationships of alkaloids from Fagara macrophylla. J Nat Prod 50: 1095-1099, 1987.

7. Quispe-Soto ET and Calaf GM: Effect of curcumin and paclitaxel on breast carcinogenesis. Int J Oncol 49: 2569-2577, 2016.

8. Wen G, Qu XX, Wang D, Chen XX, Tian XC, Gao F and Zhou XL: Recent advances in design, synthesis and bioactivity of paclitaxel-mimics. Fitoterapia 110: 26-37, 2016.

9. Bharadwaj R and Yu H: The spindle checkpoint, aneuploidy, and cancer. Oncogene 23: 2016-2027, 2004.

10. Brito DA, Yang Z and Rieder CL: Microtubules do not promote mitotic slippage when the spindle assembly checkpoint cannot be satisfied. J Cell Biol 182: 623-629, 2008.

11. Li LX, Ye SL, Wang YH and Tang ZZ: Progress on experimental research and clinical application of Trametes robiniophila. Bull Chin Cancer 16: 110-113, 2007.

12. Guo YW, Cheng PW, Chen YJ, et al: Studies on the constituents of polysaccharide from the hyphae of Trametes robiniophila (II) - identification of polysaccharide from the hyphae of Trametes robiniophila and determination of its molar ratio. $\mathrm{J}$ Chin Pharm U 23: 155-157, 1992. 
13. Guo Y, Cheng $\mathrm{P}$ and Chen Y: Isolation and analysis of the polysaccharide of Huaier mycelium. Chin J Biochem Pharm 63: 56-59, 1993.

14. Zhang N, Kong X, Yan S, Yuan C and Yang Q: Huaier aqueous extract inhibits proliferation of breast cancer cells by inducing apoptosis. Cancer Sci 101: 2375-2383, 2010.

15. Huo Q and Yang QF: Role of Huaier extract as promising anticancer drug. Adaptive Med 4: 2076-944X, 2012

16. Zhang T, Wang K, Zhang J, Wang X, Chen Z, Ni C, Qiu F and Huang J: Huaier aqueous extract inhibits colorectal cancer stem cell growth partially via downregulation of the Wnt/ $\beta$-catenin pathway. Oncol Lett 5: 1171-1176, 2013.

17. Zheng J, Li C, Wu X, Liu M, Sun X, Yang Y, Hao M, Sheng S, Sun Y,Zhang H, et al: Astrocyte elevated gene-1 (AEG-1) shRNA sensitizes Huaier polysaccharide (HP)-induced anti-metastatic potency via inactivating downstream P13K/Akt pathway as well as augmenting cell-mediated immune response. Tumour Biol 35: 4219-4224, 2014.

18. Bao H, Liu P, Jiang K, Zhang X, Xie L, Wang Z and Gong P: Huaier polysaccharide induces apoptosis in hepatocellular carcinoma cells through p38 MAPK. Oncol Lett 12: 1058-1066, 2016.

19. Xie HX, Xu ZY, Tang JN, Du YA, Huang L, Yu PF and Cheng XD: Effect of Huaier on the proliferation and apoptosis of human gastric cancer cells through modulation of the PI3K/AKT signaling pathway. Exp Ther Med 10: 1212-1218, 2015.

20. Wang X, Zhang N, Huo Q, Sun M, Lv S and Yang Q: Huaier aqueous extract suppresses human breast cancer cell proliferation through inhibition of estrogen receptor $\alpha$ signaling. Int J Oncol 43: 321-328, 2013.

21. Qi W, Sun M, Kong X, Li Y, Wang X, Lv S, Ding X, Gao S, Cun J, Cai C, et al: Huaier extract synergizes with tamoxifen to induce autophagy and apoptosis in ER-positive breast cancer cells. Oncotarget 7: 26003-26015, 2016.

22. Sen R and Baltimore D: Multiple nuclear factors interact with the immunoglobulin enhancer sequences. Cell 46: 705-716, 1986.

23. Li F, Zhang J, Arfuso F, Chinnathambi A, Zayed ME, Alharbi SA Kumar AP, Ahn KS and Sethi G: NF- $\kappa B$ in cancer therapy. Arch Toxicol 89: 711-731, 2015.

24. Wang W, Nag SA and Zhang R: Targeting the NFאB signaling pathways for breast cancer prevention and therapy. Curr Med Chem 22: 264-289, 2015.

25. Zhao N, Wang R, Zhou L, Zhu Y, Gong J and Zhuang SM: MicroRNA-26b suppresses the NF- $\mathrm{kB}$ signaling and enhances the chemosensitivity of hepatocellular carcinoma cells by targeting TAK1 and TAB3. Mol Cancer 13: 35, 2014.

26. Pommier Y, Sordet O, Antony S, Hayward RL and Kohn KW: Apoptosis defects and chemotherapy resistance: Molecular interaction maps and networks. Oncogene 23: 2934-2949, 2004.
27. Li F and Sethi G: Targeting transcription factor NF-kappaB to overcome chemoresistance and radioresistance in cancer therapy. Biochim Biophys Acta 1805: 167-180, 2010.

28. Fan L, Strasser-Weippl K, Li JJ, St Louis J, Finkelstein DM, Yu KD, Chen WQ, Shao ZM and Goss PE: Breast cancer in China. Lancet Oncol 15: e279-e289, 2014.

29. Ji D and Mai D: Effect of Huaier Granule on immunity and quality of life in patient with gastric cancer undergoing postoperative concurrent radiochemotherapy. China Cancer 19: 73-76, 2010.

30. Song X, Li Y, Zhang $\mathrm{H}$ and Yang Q: The anticancer effect of Huaier (Review). Oncol Rep 34: 12-21, 2015.

31. Jeong YJ, Kang JS, Lee SI, So DM, Yun J, Baek JY, Kim SK, Lee K and Park SK: Breast cancer cells evade paclitaxel-induced cell death by developing resistance to dasatinib. Oncol Lett 12: 2153-2158, 2016.

32. McGrogan BT, Gilmartin B, Carney DN and McCann A: Taxanes, microtubules and chemoresistant breast cancer. Biochim Biophys Acta 1785: 96-132, 2008.

33. Huang Y, Johnson K, Norris J and Fan W: NF-kB/IkB signaling pathways may contribute to the mediation of paclitaxel-induced apoptosis in solid tumor cells. Cancer Res 60: 4426-4432, 2000.

34. Bava SV, Sreekanth CN, Thulasidasan AK, Anto NP, Cheriyan VT, Puliyappadamba VT, Menon SG, Ravichandran SD and Anto RJ: Akt is upstream and MAPKs are downstream of $\mathrm{NF}-\kappa \mathrm{B}$ in paclitaxel-induced survival signaling events, which are down-regulated by curcumin contributing to their synergism. Int J Biochem Cell Biol 43: 331-341, 2011.

35. Zhang YB, Zhang GQ, Wang JS and Zhang QF: Function and clinical application of Huaier plaster in comprehensive therapy of breast cancer. Chin J Clin Oncol Rehabil 11: 6, 2004.

36. Uetsuka H, Haisa M, Kimura M, Gunduz M, Kaneda Y, Ohkawa T, Takaoka M, Murata T, Nobuhisa T, Yamatsuji T, et al: Inhibition of inducible NF-kappaB activity reduces chemoresistance to 5-fluorouracil in human stomach cancer cell line. Exp Cell Res 289: 27-35, 2003.

37. Maroun CR and Rowlands T: The Met receptor tyrosine kinase: A key player in oncogenesis and drug resistance. Pharmacol Ther 142: 316-338, 2014.

38. Raghav KP, Wang W, Liu S, Chavez-MacGregor M, Meng X, Hortobagyi GN, Mills GB, Meric-Bernstam F, Blumenschein GR Jr and Gonzalez-Angulo AM: cMET and phospho-cMET protein levels in breast cancers and survival outcomes. Clin Cancer Res 18: 2269-2277, 2012.

39. Gherardi E, Birchmeier W, Birchmeier C and Vande Woude G: Targeting MET in cancer: Rationale and progress. Nat Rev Cancer 12: 89-103, 2012. 